\title{
Correction to: Methodology to estimate ionospheric scintillation risk maps and their contribution to position dilution of precision on the ground
}

\author{
Alexandra Koulouri ${ }^{1}$ (D) Nathan D. Smith ${ }^{2} \cdot$ Bruno C. Vani $^{3} \cdot$ Ville Rimpiläinen $^{4} \cdot$ Ivan Astin $^{5} \cdot$ Biagio Forte $^{5}$
}

Published online: 5 March 2020

(c) The Author(s) 2020

\section{Correction to: \\ Journal of Geodesy (2020) 94:22 \\ https://doi.org/10.1007/s00190-020-01344-0}

Because of a typographical error during the editing process,

Eq. 23 appears incorrectly in the publication.

The correct Eq. 23 is the following:

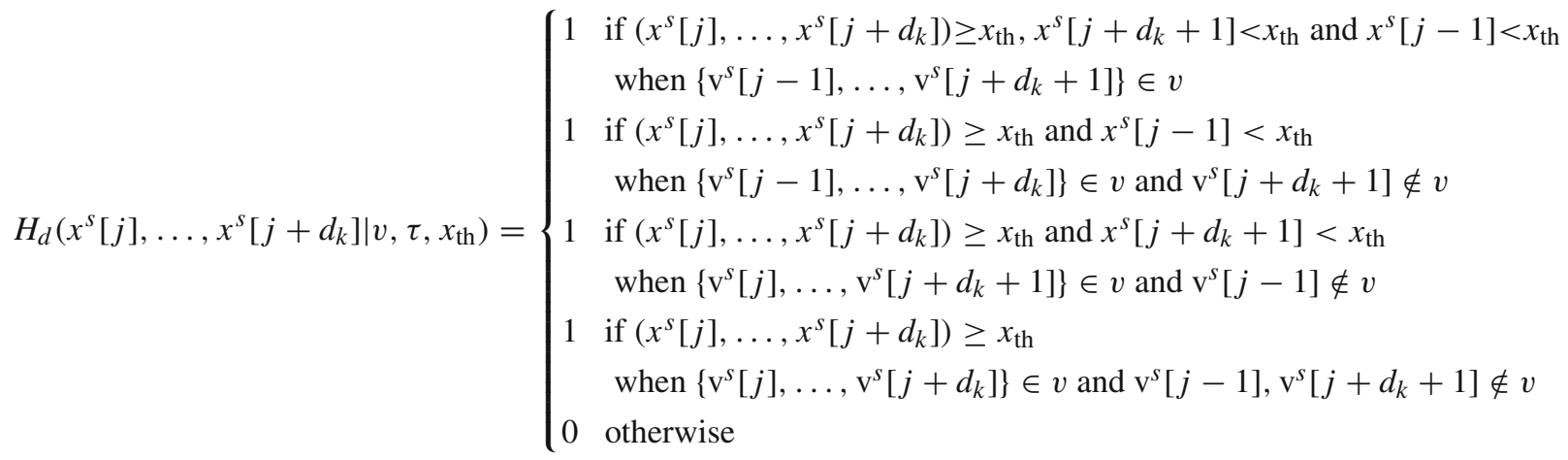

The original article can be found online at https://doi.org/10.1007/ s00190-020-01344-0.

Alexandra Koulouri

alexandra.koulouri@tuni.fi

1 Faculty of Information Technology and Communication Sciences, Tampere University, P.O. Box 692, 33101 Tampere, Finland

2 Bath, UK

3 Department of Informatics, Federal Institute of Education, Science and Technology of Sao Paulo, Campus Presidente Epitacio, Rua José Ramos Jr, 27-50 Presidente Epitacio, Sao Paulo, Brazil

4 Department of Physics, University of Bath, Bath BA2 7AY, UK

5 Department of Electronic and Electrical Engineering, University of Bath, Bath BA2 7AY, UK
Open Access This article is licensed under a Creative Commons Attribution 4.0 International License, which permits use, sharing, adaptation, distribution and reproduction in any medium or format, as long as you give appropriate credit to the original author(s) and the source, provide a link to the Creative Commons licence, and indicate if changes were made. The images or other third party material in this article are included in the article's Creative Commons licence, unless indicated otherwise in a credit line to the material. If material is not included in the article's Creative Commons licence and your intended use is not permitted by statutory regulation or exceeds the permitted use, you will need to obtain permission directly from the copyright holder. To view a copy of this licence, visit http://creativecomm ons.org/licenses/by/4.0/. 